\title{
Caroline Vout Power and Eroticism in Imperial Rome
} Cambridge University Press, 2007. Pp.xiv + 285, 52 figs. ISBN 978-0-521. 86739-9. \$99.00 US cloth.

The history of sexuality has been a hot and trendy topic of late in all fields of historical scholarship, but it is one that has somewhat lagged behind in the area of ancient Greek and Roman studies. However, in the last decade or so there have been a series of books dealing with the subject, with particular emphasis on the Latin erotic poetry of Catullus and Ovid, but also from the perspective of what the art and archaeological sources tell us. Also, many authors, both ancient and modern, have related the sometimes scandalous and over-the-top sexual exploits of the Roman emperors, but more so as a matter of fascination, entertainment, and vilification. Nonetheless, such tales have the potential to reveal elements concerning not only the morals of the emperor and of Roman society as a whole, but also what sexuality and reactions to it can tell us about how Romans understood their own identity. Caroline Vout's new book examines the concept of sex and power (6-7), but in particular provides a new perspective on how the sex lives of the emperors and the emperors' sexuality, as portrayed in both literary sources and visual media such as sculpture, reveals how Romans perceived themselves in relation to the emperor and their place in the Roman Empire itself.

The book spans a total of six chapters and includes not only a general index, but also an index of all principal passages by ancient authors cited in the main text. The first chapter entitled "The erotics of imperium", is essentially an introduction

$$
\begin{gathered}
\text { Past Imperfect } \\
14 \text { [2008) | (C) |ISSN 1711-053X| elSSN 1718-4487 }
\end{gathered}
$$


outlining the aims of the book, as well as the methodology used. This chapter is followed by chapters each consisting of a case study pertaining to a particular emperor. Each study is unique in terms of the type of sexual relationship explored, but more importantly how it was viewed in either the literary or visual sources. The author provides the ancient literary texts in their original Greek and Latin and provides an English translation which makes this evidence accessible to a wide audience. She also makes the reader aware of the state of the evidence and the strengths and limitations present therein (57). For each case study presented in the book, Vout meticulously and conscientiously selects both literary and visual evidence which is focused so as to reveal key themes/elements pertaining to the emperor's sexuality and identity, the identity of imperial subjects, and the possible perceptions these members of Roman imperial society had regarding the emperor's power and sexuality. Vout essentially takes one body of evidence (usually a selection or series of selections from ancient authors), isolates a particular theme, and then endeavors to qualify it by means of another body of evidence (literary and/or visual). For example, in chapter 2 which deals with the emperor Hadrian and his male Bithynian lover Antinous, the author takes selections from ancient authors such as Cassius Dio and Pausanius, as well as the Scriptores Historiae Augustae. Vout explains that these sources are only able to reconstruct a quasi-biography of Antinous, but nonetheless are indispensable in gleaning perceptions and attitudes spanning several centuries which indicate that Antinous was perceived both as a god and a hero. She then endeavors to substantiate Antinous's divine identity by examining the visual evidence in order to tap into Antinous's "influence and authority as a 'god"”

Past Imperfect 14 [2008] | ( ) |ISSN 1711-053X | eISSN 1718-4487 
(61). Here, Vout tends to get caught up in a discussion about the particulars surrounding the identification and authenticity of Antinous's images, which should not be disregarded. However, it tends to detract from the more important issues she touches on such as how the visual image of Antinous made the viewer think about his/her relationship to the emperor and Roman imperial 188) society (112).

In chapter 3, Vout introduces the reader to Nero's eunuch bride Sporus by means of Suetonius and Cassius Dio. She compares this relationship to that of a particular Roman prefect of Egypt, C. Vibius Maximus, who had an open and public love affair with a 17 year old Alexandrian youth, as outlined in the Papyrus Oxyrynchus 471 (140-151), a document of Hadrianic or Antonine date. This document discusses Maximus's legal offences and argues that Maximus's relationship with the youth was not only offensive to the "Greekness" of local Alexandrians, but was likely perceived in Roman society as scandalous, un-Roman, and too excessively Greek-like. Vout's comparison of Nero's homosexual relationship with that of Maximus reveals that Romans clearly admired and indulged in Greek-like homosexual relations. Yet at times such relations were considered excessive and potentially detrimental to the status and integrity of both the Roman male citizen and Greek subjects

of empire alike.

Vout's comparative analyses continue in chapter 4, which deals with the emperor Domitian's homoerotic relationship with the eunuch Earinus. Here, Vout provides a detailed literary analysis of the poetry of Martial and Statius, contemporaries of the Domitian and his lover Earinus, and that of the Roman

$$
\begin{gathered}
\text { Past Imperfect } \\
14 \text { [2008] | (C) |ISSN 1711-053X | eISSN 1718-4487 }
\end{gathered}
$$


Republican poet Catullus's poem 63 which discusses the castrated god Attis (191 ff). Vout's discussion of this poetry reveals the Roman poet's attitude towards homoerotic love, especially from the perspective of the patron-client relationship that was so central to Roman society. Such relationships included both dominant master and submissive subject. The Roman poet's status as client to the emperor is reflected in their portrayal of Domitian's relationship with Earinus, who is dominated sexually by the emperor.

The penultimate chapter moves from the homosexual to heterosexual relations of the emperor by exploring the heterosexual relationship the emperor Lucius Verus had, not with his wife Lucilla, but with his mistress Panthea from Smyrna. Vout delves into the question of what the gender, body and eastern roots of Panthea represents in terms of emperor and his power. The character and identity of Panthea, as described in contemporary literary sources such as Lucian, are analyzed in conjunction with Homer's portrayal of Briseis in the Iliad. Vout argues that Lucian has developed his description of Panthea on the model of Briseis, who was also a foreign mistress of a great king. What is noteworthy is not the similarity between these two female figures, but rather what they represent: the conquered "other". Briseis represents the Greeks' domination of the Trojans, while Panthea represents Rome's conquest of Greece.

Vout's comparative approach to analyzing the literary and material evidence is effective in bringing to light potential perceptions Romans and other members of Roman imperial society may have had regarding not only the identity and sexuality of the emperor, but also their own identity and sexuality. However, a potential problem lies in the fact that some 
of the evidence Vout presents is far displaced chronologically from the emperors she examines in each of her case studies: Suetonius was born after Nero's death and flourished under Hadrian; Catullus preceded Martial and Statius by more than a century; Homer's works preceded Lucian by more than half a millennium at least. Is Vout superimposing the meanings/themes 190 derived from these literary sources onto contemporary sources concerning the emperors in question? She does appear to be using one type of evidence/media in an attempt to derive meanings and theories about another: she argues that literary sources such as Cassius Dio and Pausanius "can be used to inform his (Antinous's) extant images." (65) Vout's approach to visual culture is stated explicitly at the beginning of the book when she states that "visual culture is informed by literature and its stories." (6) While Vout's approach does provide a series of potential interpretations regarding the emperor's sexuality and Roman identity, one must be careful not to "read into" the evidence too much without substantiating it with other evidence (if it exists) that is roughly contemporaneous to each particular emperor.

Vout's analysis of the emperors' sexuality and that of their lovers, as revealed in literary and visual sources, certainly accomplishes Vout's goal of revealing previously unseen elements surrounding Roman imperial "male" identity. The book's title Power and Eroticism in Imperial Rome implies that power and sexuality are connected, as Vout asserts in her introduction. Here, Vout states explicitly that "Imperium equals sex..."(5) without adequately isolating what the term imperium meant to the Romans. Vout seems to be assuming that imperium is synonymous with "power" as a whole, when in fact this term refers to the emperor's power in an official and legal sense as 
granted by the Roman Senate. What Vout is in fact dealing with more so is the emperor's auctoritas, his overall power and influence in Roman imperial society. Furthermore, the whole issue of power and what this means in terms of identity tends to take a back seat throughout most of the book. However, it does come into play in a very informative way in her discussion regarding Hadrian and Antinous's relationship. Vout argues that the literary and visual evidence indicates that Antinous had a significant impact on the emperor and his power. Most importantly, Vout shows how multifaceted perceptions of the emperor resulted from his relationship with Antinous. On the one hand, Hadrian's relationship with Antinous was compared with that of Jupiter and Ganymede, indicating that Hadrian's "loving like a god" makes him appear as a deity (113), which in turn reveals an aspect of the emperor's power and sexual potency. On the other hand, the emperor also appeared to be "weakened" by his love for Antinous in the sense that he was vulnerable to the power of Eros, god of love, and the potency of Antinous's own beauty and sexuality (113).

While Vout endeavors to provide insight into the homosexual and heterosexual relations of particular emperors, her analysis is weighted far too heavily towards the emperors' homosexual escapades, which leaves the reader with a somewhat skewed perspective about their collective sexuality and its impact on Roman imperial society, especially as it relates to the power of the emperor in relation to his imperial subjects. A key issue that the author needed to address in order to provide a more complete picture of the emperor's sexuality and how it relates to Roman identity would be to examine the heterosexual relations the emperors had with their wives. These husband-wife relationships

$$
\begin{gathered}
\text { Past Imperfect } \\
14 \text { [2008] | (C) |ISSN 1711-053X | eISSN 1718-4487 }
\end{gathered}
$$


probably had the most impact on Roman society, especially as it relates to the emperor's power, influence and identity, given that it was through these women that imperial dynasties were maintained.

While much previous scholarship has primarily explored Roman sex and sexuality by means of the "stories" the literary 192 evidence tells us about it and how Roman art portrays it, Vout's book makes a significant contribution to a deeper understanding of Roman sexuality and how it reveals aspects of social and political identity, especially as it pertains to the Roman emperor and his imperial subjects. In exploring how the emperor's sexuality affects identity, Vout provides a unique and fresh approach which will create ample food for thought and much interesting discussion for further scholarship.

Tracene Harvey, University of Alberta 